\title{
IMPACT OF CANAL RESTRUCTURING ON AGRICULTURAL LAND USE IN 23 DOWN HAIDERGARH CANAL COMMAND SYSTEM, UTTAR PRADESH, INDIA
}

\author{
Pramod Kumar Yadav ${ }^{1}$, Pragati Singh ${ }^{1}$, Narendra Kumar ${ }^{2}$, R. K. Upadhyay ${ }^{1}$, S. P. S. Jadaun ${ }^{1, *}$ \\ Remote Sensing Applications Centre Uttar Pradesh, Lucknow India \\ ${ }^{1}$ (ce1005600053, singh22pragati, shivpalsingh.jadaun, rsacupard)@gmail.com \\ 2(rsacupnk@rediffmail.com)
}

Commission III, WG III/10

KEYWORD: Agricultural land use, canal line, restructuring, Sodic land, waterlogged.

\begin{abstract}
:
The 23 Down Haidergarh Canal command system of Uttar Pradesh is situated in Indo-Gangetic Plain of India. It has huge potential of crop productivity. The canal system was unlined; due to which a huge amount of water waste as seepage, which results, waterlogging and sodic land development. This leads reduction in the productivity of crop land. To overcome with this problem government started the restructuring/lining of canal in 23 Down Haidergarh canal command system. The present study was an attempt to find out the changes in agricultural land of rabi season because during rabi season canal is important source of irrigation in 23 Down Haidergarh canal command system. Remote sensing and GIS techniques were used to monitor the changes after the restructuring of canal system. The LISS-III data (Linear Imaging Self-Scanner) of Rabi season for the year 2011-12 and 2017-18 was used for mapping of agricultural land use changes in rabi season for23 Down Haidergarh canal command system. This study is useful to find out the change in agricultural land after the restructuring of canal command system.
\end{abstract}

\section{INTRODUCTION}

It is well known fact that if canal irrigation project are taken up without due consideration to slope and field drainage, extensive water logging and salt accumulation occurs shortly after the inception of the project. Uttar Pradesh is having good networks of canal for distributing irrigation water for crop growing. In Uttar Pradesh canals are generally unlined and a huge quantity of water goes as waste due to seepage and field related losses. According to an estimate out of 14.06 million ha cultivable area of command area of 42 canal irrigation projects in country, about 1.6 million ha areas is suffering from water logging whereas in Uttar Pradesh 87694 ha. area was waterlogged in 2010 (National wetland atlas Uttar Pradesh).

The 23 Down Haidergarh branch, is a branch canal of Sharda Sahayak canal system, constructed on main Sharda canal after $22.98 \mathrm{~km}$ down in Haidergarh town, that's why it is called 23 down Haidergarh canal command area. The total length of the 23 down Haithergarh canal is around 39064.53 meters. Which consist $7528.20 \mathrm{~m}$ under main branch, $7336.45 \mathrm{~m}$ under 19 distributaries and $24199.88 \mathrm{~m}$ under 160 minors.

Before restructuring of canal on a 10 years average there were 19787 ha. area was irrigated but after this project completion, irrigated area was increased around 28285 ha which is around 8498 ha. Which provide benefit around 54124 farmers in the study area, in which around 28314 farmers from Barabanki, 28341 from Sultanpur and 25783 from Amethi district.

When the canal system was developed it was unlined. Due to which, the seepage and over irrigation works happened in this area which results waterlogging and sodic land development in the study area. By which the crop land and productivity reduced in the study area. To overcome this serious problem, government started the canal lining. The 23 Down Haidergarh main branch of canal is lined around $\mathbf{1 0} \mathbf{~ k m}$, each distributaries are $\mathbf{1 0 0}$ meters line and all minor are $\mathbf{5 0} \mathbf{~ m}$ lined till 1 January 2018. This results decrease in waterlogged and sodic land area and increase in the crop land of the 23 Down Haidergarh canal command area. This study is an attempt towards monitoring the change in water logged area and sodic land due to canal lining and other development works using the satellite remote sensing data and geographic information system.

\section{STUDY AREA\& DATA SETS USED}

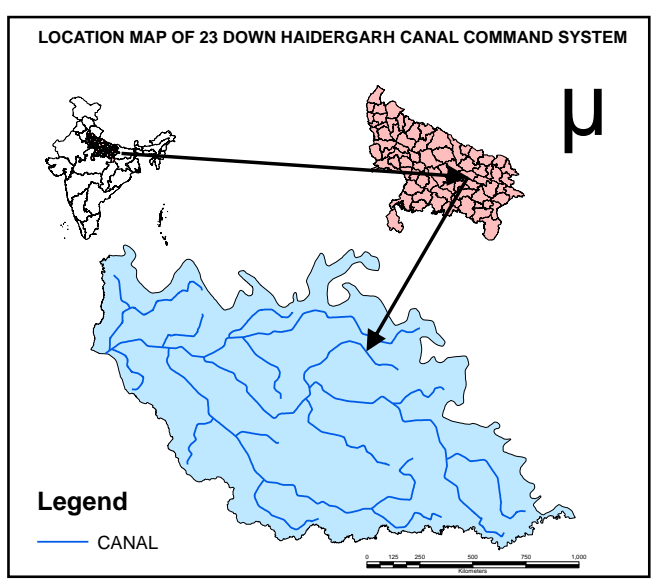

Figure 1: Location map of study area

23 down Haidergarh canal command area is the parts of four districts of Uttar Pradesh; viz.,Barabanki, Amethi, Raibareli and Sultanpur.

Geographically Haidergarh (23 down) extends from $81^{0} 16^{\prime} 25.31^{\prime \prime} \mathrm{E}$ to $82^{\circ} 8^{\prime} 23.628^{\prime}{ }^{\prime} \mathrm{E}$ and $26^{0} 48^{\prime} 53.271^{\prime \prime} \mathrm{N}$ to $26^{0} 21^{\prime} 18.064$ ' 'N.Command Area extends from 81016'25.31' 'E to $81^{0} 42^{\prime} 3.955^{\prime \prime} \mathrm{E}$ and $26^{\circ} 41^{\prime} 27.447^{\prime} \mathrm{N}$ to $26^{0} 23^{\prime} 32.555^{\prime}{ }^{\prime} \mathrm{N}$. Climatic conditions of Haidergarh is moderate.

The Haidergarh Branch Canal takes off from the main feeder channel (left bank) at $171.50 \mathrm{Km}$ and the total length of this branch is $30.98 \mathrm{Km}$. The total length of the canal system associated with Haidergarh Branch Km. 22.98 down including 
branch, distributaries and minors is $685.57 \mathrm{Km}$. The numbers and length of associated drainage network in this command is 291 numbers and $721.68 \mathrm{Km}$. respectively. The total area of the Haidergarh Branch Canal Command Area is 102179.49ha.

The data sets which were used in this study are given in Table no.1

\begin{tabular}{|c|c|c|c|c|c|c|}
\hline S.N & SATELLITE & SENSOR & РATH & ROW & DATE & PURPOSE \\
\hline 1 & IRS-P6 & LISS-III & 100 & 53 & $02-11-10$ & \multirow{2}{*}{$\begin{array}{c}\text { WATER } \\
\text { LOGGED }\end{array}$} \\
\hline 2 & IRS-P6 & LISS-III & 101 & 53 & $07-11-10$ & \\
\hline 3 & IRS-P6 & LISS-III & 100 & 53 & $06-02-11$ & \multirow{2}{*}{$\begin{array}{l}\text { SODIC } \\
\text { LAND }\end{array}$} \\
\hline 4 & IRS-P6 & LISS-III & 101 & 53 & $11-02-11$ & \\
\hline 5 & Resourcesat $2 \mathrm{~A}$ & LISS-III & 100 & 53 & $17-02-18$ & \multirow{2}{*}{$\begin{array}{l}\text { SODIC } \\
\text { LAND }\end{array}$} \\
\hline 6 & Resourcesat 2A & LISS-III & 101 & 53 & $22-02-18$ & \\
\hline 7 & Resourcesat 2A & LISS-III & 100 & 53 & $08-11-18$ & \multirow{2}{*}{$\begin{array}{c}\text { WATER } \\
\text { LOGGED }\end{array}$} \\
\hline 8 & Resourcesat 2A & LISS-III & 101 & 53 & $13-11-18$ & \\
\hline
\end{tabular}

Table 1: Description of datasets used

\section{METHODOLOGY}

To extract the area under sodic land, waterlogged and agricultural land there were three techniques used in this research work. the method used in this research work are;

3.1 GIS DATA Preperation:Using ARCGIS software the canal lining, sodic land, waterlogged, waterbody, settelment and roads were digitized. These layers were used to find out the area under sodic land and water logged during rabi season in the year 2011-12 to 2017-18. Which was used in change detection of sodic land, water logged and agricultural area after the canal restructuring.

3.2 IMAGE CLASSIFICATION: There were two image classification techniques used in this research work; Supervised and unsupervised. Using both the classification techniques there were sodic land, waterlogged, waterbody, settelment and roads were classified. Which was was used in change detection of sodic land, water logged and agricultural area after the canal restructuring.

Using the following categories given in table no 2 , the sodic land was classified in different categories;

\begin{tabular}{|c|c|c|c|}
\hline $\begin{array}{c}\text { SL } \\
\text { NO. }\end{array}$ & pH & EC & Category \\
\hline $\mathbf{1}$ & 7 to 8 & 0 to 4 & non saline \& slight sodic \\
\hline $\mathbf{2}$ & 7 to 8 & 4 to 8 & slight saline \& slight sodic \\
\hline $\mathbf{3}$ & 7 to 8 & 8 to 16 & Moderate saline and slight sodic \\
\hline $\mathbf{4}$ & 7 to 8 & $>16$ & strong saline \& slight sodic \\
\hline $\mathbf{5}$ & 8 to 8.5 & 0 to 4 & non saline \& moderate sodic \\
\hline $\mathbf{6}$ & 8 to 8.5 & 4 to 8 & slight saline \& moderate sodic \\
\hline $\mathbf{7}$ & 8 to 8.5 & 8 to 16 & Moderate saline and moderate sodic \\
\hline $\mathbf{8}$ & 8 to 8.5 & $>16$ & strong saline \& moderate sodic \\
\hline $\mathbf{9}$ & 8.5 to 9 & 0 to 4 & non saline \& strong sodic \\
\hline $\mathbf{1 0}$ & 8.5 to 9 & 4 to 8 & slight saline \& strong sodic \\
\hline $\mathbf{1 1}$ & 8.5 to 9 & 8 to 16 & Moderate saline and strong sodic \\
\hline $\mathbf{1 2}$ & $>8.5$ & $>16$ & strong saline \& strong sodic \\
\hline & & & \\
\hline
\end{tabular}

\begin{tabular}{ll|l}
$\mathbf{1 3}$ & $<7$ & Alkaline \\
\hline
\end{tabular}

Table 2: Description of sodic land category

3.3 GROUND TRUTH DATA COLLECTION : The ground truth data for waterlogged, canal linning and soil samples for sodic land assesment colected from the field. Soil soil samples taste for sodic soil identifivation was done in laboratory by tasting the $\mathrm{pH}$ and EC values of different soils. These samples were used in the accuracy assesment. Table no. 3 represent the charectristics of soil samples collected from the ground;

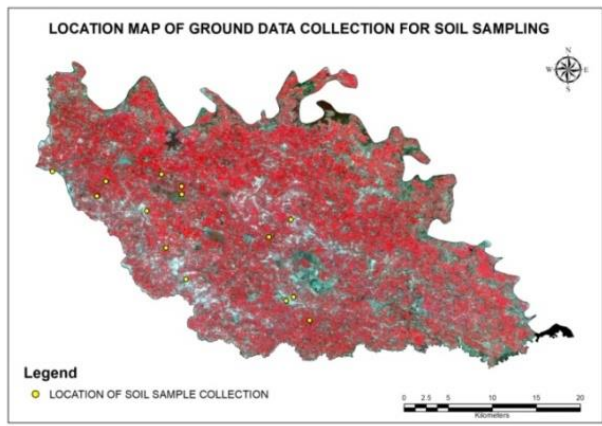

Figure 2: Locations for ground soil samples

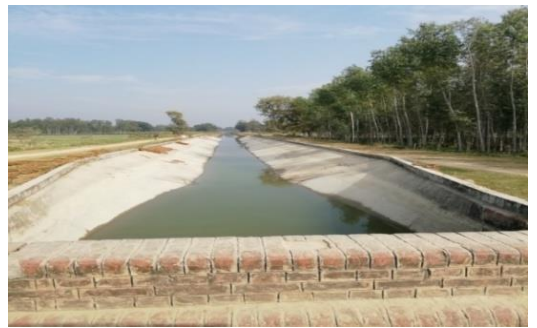

Figure 3: Restructured image of Haidergarh canal

\begin{tabular}{|c|c|c|c|c|c|c|}
\hline S.NO & LATITUDE & LONGITUDE & pH & EC & OC & CATEGORIES \\
\hline 1 & 26.59336 & 81.29083 & 6.8 & 0.94 & 1.965 & $\begin{array}{l}\text { alkaline \& non } \\
\text { saline }\end{array}$ \\
\hline 2 & 26.59051 & 81.40227 & 6.4 & 0.57 & 1.179 & $\begin{array}{l}\text { alkaline \& non } \\
\text { saline }\end{array}$ \\
\hline 3 & 26.57802 & 81.42253 & 6.2 & 0.36 & 0.9825 & $\begin{array}{l}\text { alkaline \& non } \\
\text { saline }\end{array}$ \\
\hline 4 & 26.57006 & 81.42299 & 5.3 & 0.36 & 2.45625 & $\begin{array}{l}\text { alkaline \& non } \\
\text { saline }\end{array}$ \\
\hline 5 & 26.52641 & 81.51203 & 5.4 & 0.23 & 0.9825 & $\begin{array}{l}\text { alkaline \& non } \\
\text { saline }\end{array}$ \\
\hline 6 & 26.5442 & 81.53434 & 9.5 & 0.75 & 0.393 & $\begin{array}{l}\text { strong sodic\& non } \\
\text { saline }\end{array}$ \\
\hline 7 & 26.58329 & 81.34566 & 7.4 & 0.79 & 1.35585 & $\begin{array}{l}\text { slight sodic\& non } \\
\text { saline }\end{array}$ \\
\hline 8 & 26.56817 & 81.33664 & 8.1 & 0.61 & 0.7074 & $\begin{array}{c}\text { moderate sodic \& non } \\
\text { saline }\end{array}$ \\
\hline 9 & 26.58321 & 81.3456 & 7 & 0.74 & 0.92355 & $\begin{array}{l}\text { slight sodic\& non } \\
\text { saline }\end{array}$ \\
\hline 10 & 26.56806 & 81.33632 & 6.1 & 0.72 & 2.5152 & alkaline \& non saline \\
\hline 11 & 26.55314 & 81.38712 & 6.6 & 0.73 & 0.9432 & alkaline \& non saline \\
\hline 12 & 26.4834 & 81.42727 & 10 & 4.3 & 0.4716 & $\begin{array}{l}\text { strong sodic \& slight } \\
\text { saline }\end{array}$ \\
\hline 13 & 26.46519 & 81.53679 & 10.97 & 9.5 & 0.72705 & $\begin{array}{c}\text { strong sodic\& } \\
\text { moderate saline }\end{array}$ \\
\hline 14 & 26.51545 & 81.4069 & 8.3 & 0.87 & 0.88425 & $\begin{array}{c}\text { moderate sodic\& non } \\
\text { saline }\end{array}$ \\
\hline 15 & 26.44149 & 81.55319 & 10.7 & 8.4 & 1.527 & $\begin{array}{l}\text { strong sodic\& } \\
\text { moderate saline }\end{array}$ \\
\hline 16 & 26.46154 & 81.52952 & 9.6 & 1.2 & 0.33405 & $\begin{array}{l}\text { strong sodic\& non } \\
\text { saline }\end{array}$ \\
\hline 17 & 26.51863 & 81.30726 & & & & sodic \\
\hline
\end{tabular}

Table 3: Soil sample characteristics 
Using the following $\mathrm{pH}$, EC values the different categorises of sodic land was classified by supervised and unsupervised classification technique in ERDAS IMAGINE software

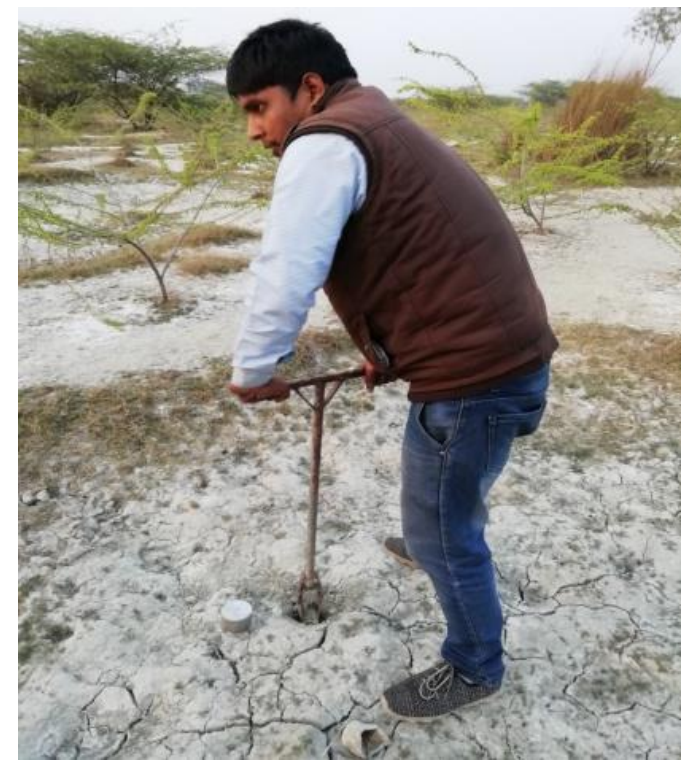

Figure 4: Soil sample collection for sodic soil

3.4 COMPARITIVE ANALYSIS : The comparitive analysis was done between the output resulted from supervised, unsupervised and digitized area of different classes to find that which technique perfoms better for the study.

The following flowchart in figure 2 illustrate the methodology followed in this research work:

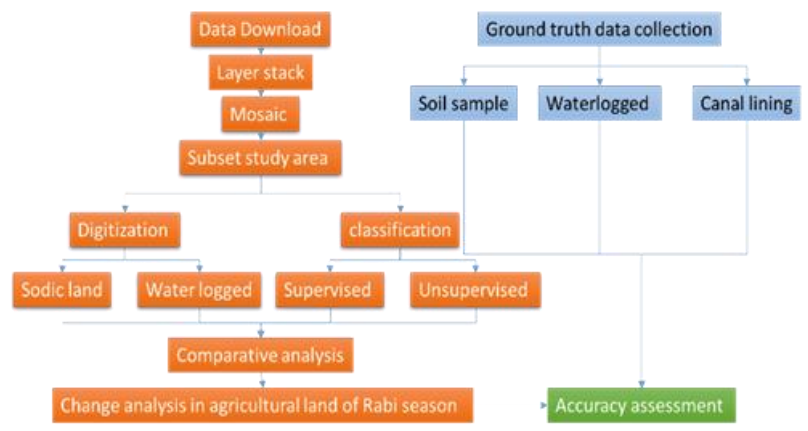

Figure 5: Methodology flow chart

\section{RESULT \& DISCUSSION}

Canal is the major source of irrigation in the study area but it affects the fertility of the agricultural land because of conversion of agricultural land into waterlogged and sodic land.To solve this issue due to canal seepage the restructuring in the canal lining was done. This study results by comparing the 2011-12 and 2017-18 LISS 3 Satellite image, after the restructuring of canal lining the area under sodic and water logged was decline and agricultural land was inclined.

This study was done by the three different image interpretation method as; Digitization, supervised and unsupervised classification techniques to identify the area under sodic, waterlogged and agriculture; before and after the canal lining.

By this study we found that, the unsupervised classification technique performs better to classify different types of sodic land and the area under sodic land was properly classified than the supervised and digitization techniques. The supervised classification technique was over estimate the area and also it was not capable to classify the different categories of sodic land. Whereas by the digitization small pixels surrounded by vegetation were not properly digitized, that's why some of the sodic land was left. Which results the under estimation of the area under sodic land, as well as it was not suitable for categorizing different type of sodic land.

The sodic land, waterlogged, agricultural land and water bodies for the year 2011-2012 to 2017-2018 was classified using three major techniques viz. unsupervised, supervised and digitization technique. The classified maps of land use categories by the unsupervised, supervised and digitization techniques can be seen from the figure no. 6 to 11

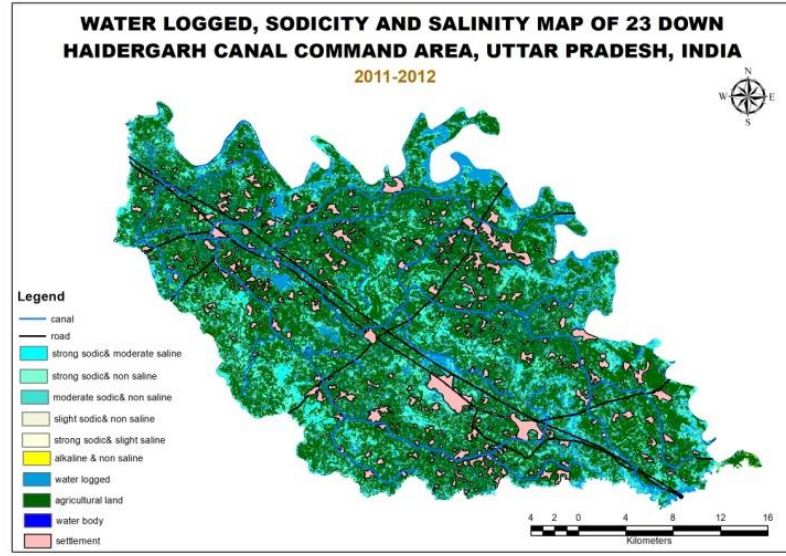

Figure 6: Land use categories by Unsupervised technique for the year 2011-2012

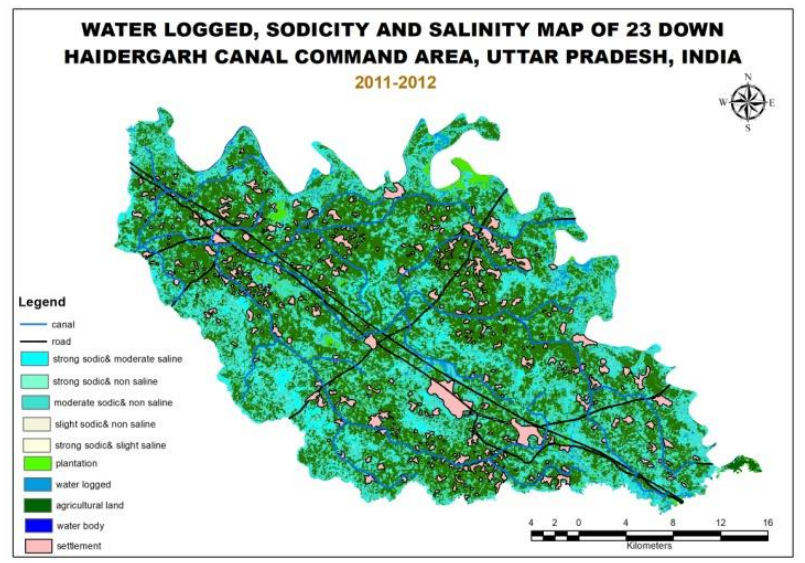

Figure 8: Land use categories by Supervised technique for the year 2011-2012 


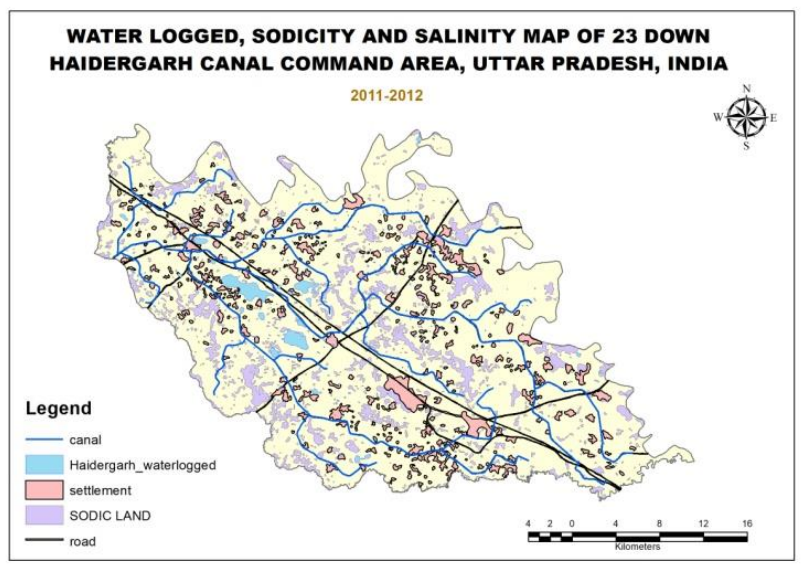

Figure 10: Land use categories by Digitization for the year 2011-2012

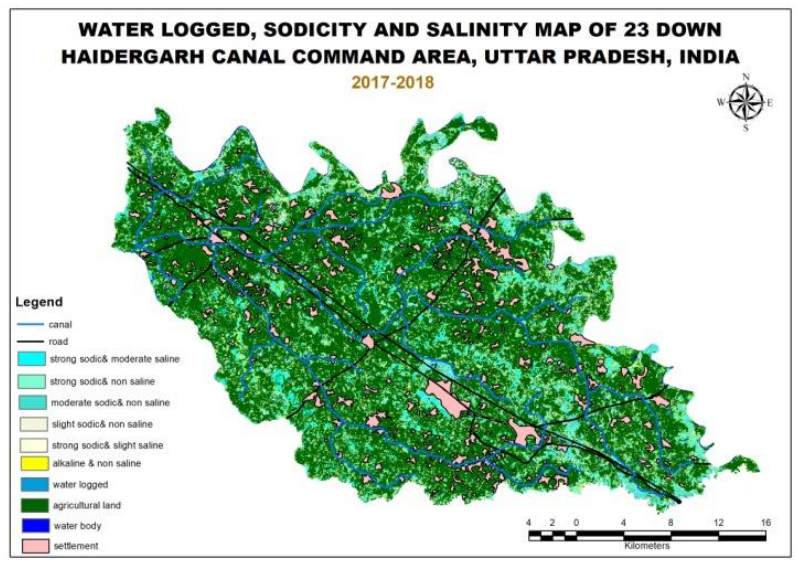

Figure 7: Land use categories by Unsupervised technique for the year 2017-2018

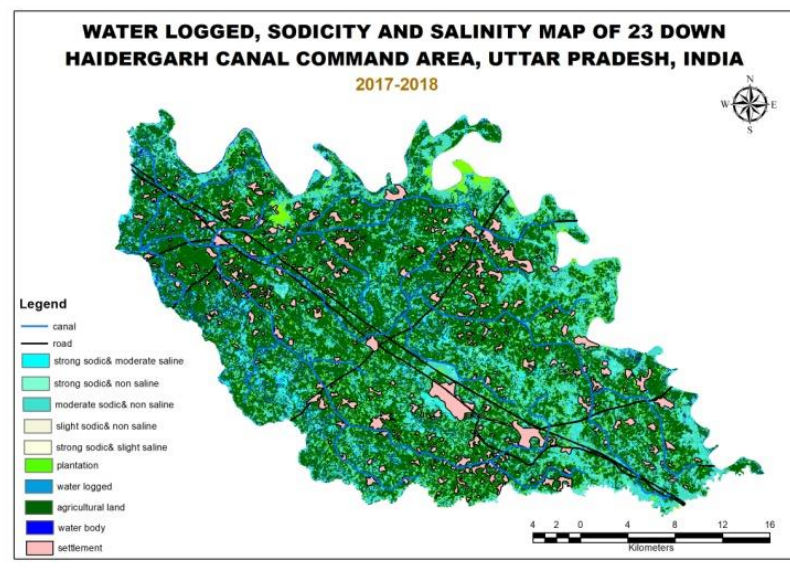

Figure 9: Land use categories by Supervised technique for the year 2017-2018

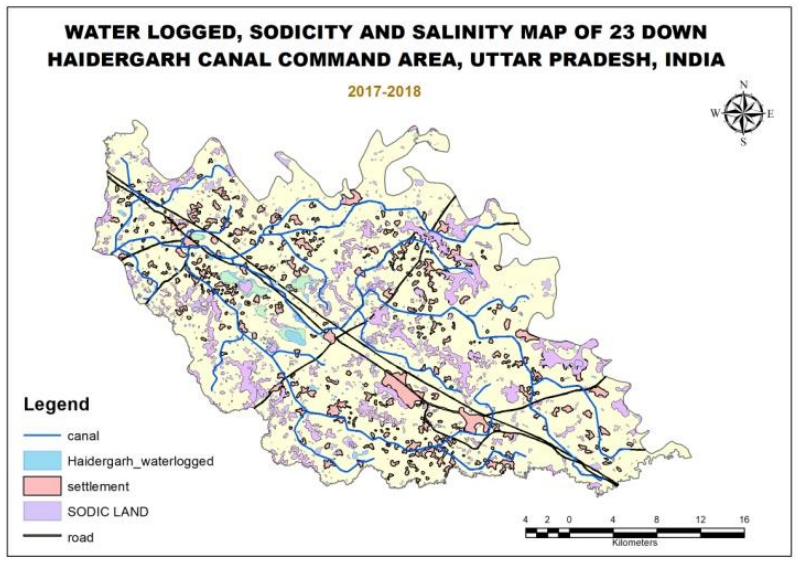

Figure 11: Land use categories by Digitization for the year 2017-2018

By the figure no. 6 and 7 we can find out the change in sodic and water logged areas as well as change in the different categories of sodic lands can be also seen. The result of unsupervised classification properly illustrates the decrease in different sodic land categories and waterlogged areas and increase in the agricultural land. Whereas by the figure no 8 and 9 it can see that the supervised technique overestimates the sodic land and under estimate the agricultural land as well as the different categories of sodic land was not properly classified. By the figure no. 10 and 11 which results of digitization, it can be seen that the large pockets of sodic and waterlogged land were only digitized. The small lands which are surrounded by crops were not digitized.

By visualizing the map of 2011-12 to 2017-18 classified by three techniques, area under sodic and waterlogged decreased and increase in agricultural lands.

Table no. 4 and 5 represent the area under different sodic land categories, water logged, agricultural land and water body of the study area by unsupervised and supervised classification techniques for the year 2011-12 to 2017-18 whereas table no 6 represent the sodic land and water logged area by different classification and the changes in the sodic and water logged categories in $\%$ by supervised, unsupervised and digitization techniques;

\begin{tabular}{|l|r|r|}
\hline Land use Classes & $\begin{array}{r}2011-12 \\
\text { Area (ha) }\end{array}$ & $\begin{array}{r}2017-2018 \\
\text { Area (ha) }\end{array}$ \\
\hline water body & 337.8 & 529.12 \\
\hline water logged & 5528.8 & 4695.92 \\
\hline $\begin{array}{l}\text { agricultural \& alkaline, non saline } \\
\text { land }\end{array}$ & 56652.72 & 69849.16 \\
\hline strong sodic\& moderate saline & 3670.72 & 4614.88 \\
\hline moderate sodic\& non saline & 10608.56 & 4308.56 \\
\hline strong sodic\& non saline & 6564.88 & 3534.4 \\
\hline slight sodic\& non saline & 2570.36 & 1964.32 \\
\hline strong sodic\& slight saline & - & 2155.44 \\
\hline
\end{tabular}

Table 4: Landuse classes by Unsupervised classification 


\begin{tabular}{|l|r|c|}
\hline Land use Classes by sup & $\begin{array}{l}\text { 2011- } \\
\mathbf{2 0 1 2} \\
\text { Area (ha) }\end{array}$ & $\begin{array}{l}\text { 2017- } \\
\mathbf{2 0 1 8} \\
\text { Area (ha) }\end{array}$ \\
\hline water body & 129.44 & --- \\
\hline strong sodic\& moderate saline & 3758.48 & 2080.32 \\
\hline strong sodic\& non saline & 1717 & 2837.28 \\
\hline moderate sodic\& non saline & 25563.8 & 20221.8 \\
\hline water logged & 3285.44 & 2240.44 \\
\hline Crop & 45075 & 51656.3 \\
\hline Plantation & 3699.12 & 8655.84 \\
\hline & & \\
\hline
\end{tabular}

Table 5: Landuse classes by Supervised classification

\begin{tabular}{|c|c|r|r|r|}
\hline Technique & $\begin{array}{c}\text { Land use } \\
\text { Classes }\end{array}$ & $\begin{array}{c}\text { 2011-12 } \\
\text { Area } \\
\text { (ha) }\end{array}$ & $\begin{array}{c}\text { 2017-18 } \\
\text { Area } \\
\text { (ha) }\end{array}$ & Change (\%) \\
\hline Unsupervised & Sodic land & 23414.52 & 16577.6 & 29.2 \\
\hline Supervised & Sodic land & 31039.28 & 25139.4 & 19.01 \\
\hline Digitized & Sodic land & 10433.64 & 8714.61 & 16.47 \\
\hline Unsupervised & water logged & 5528.8 & 4695.92 & 15.06 \\
\hline Supervised & water logged & 3285.44 & 2240.44 & 31.80 \\
\hline Digitized & water logged & 250.09 & 151.34 & 39.48 \\
\hline
\end{tabular}

Table 6: Sodic land \& waterlogged classes by different techniques

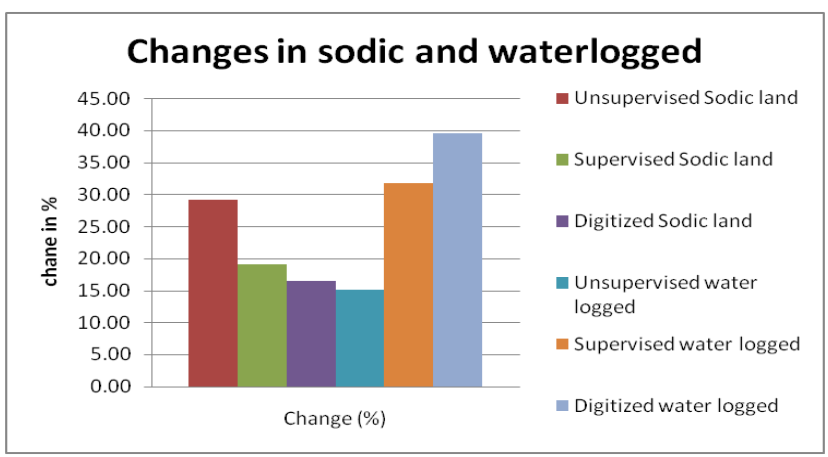

Figure 12: Changes in sodic land and waterlogged areas

By the table no 4, 5 and 6; it can be see that when the canal restructuring was started in the year 2011 the area under different categories of sodic land and water logged areas was in a large no. but after the completion of canal restructuring these areas were reduced and an increment in agricultural land can be seen during the year 2017-2018.

The sodic land classes defined by the unsupervised classification technique in table no. 4 illustrate the importance of canal restructuring on sodic, waterlogged and agricultural land in 23 Down Haidergarh canal command system as well as different categories of sodic lands were properly classified. The table represent the reduction in sodic land and waterlogged area from the year 2011-2012 to 2017-2018, whereas increase in agricultural land and water body respectively.

In the table no. 5 it was find out that, the supervised technique overestimated the sodic land and under estimated the agricultural land as well as the different categories of sodic land was not properly classified. As well as area under the water bodies became nil in 2017-18 from 2011-12.

Table no. 6 and figure no 12 represents the changes in sodic and waterlogged areas in \% from 2011-2012 to 2017-2018. By the table and graph it can be seen that the maximum changes in sodic land was found by the unsupervised classification technique than supervised and digitization whereas by supervised technique in water logged areas. But the result from the unsupervised is more accurate than the others.

\section{CONCLUSION}

By this study it was concluded that, due torestructuring of canal lining the agricultural land degradation due to water logging and sodicity reduced. The sodic and waterlogged areas were decreased and the agricultural lands were increased.

By this study it was also found that the unsupervised classification technique is better than supervised and digitization to discriminate the sodic land categories as well as for the proper classification of sodic and waterlogged area.

\section{REFERENCES}

Bahadur, L., Tiwari, D.D., Mishra, J. and Gupta, B.R., 2013. Evaluation of integrated nutrient management options in rice (Oryzasativa) wheat (Triticumaestivum) cropping system in reclaimed sodic land. Indian Journal of Agronomy, 58(2), pp.137-145.

Dagar, J.C., 2009. Opportunities for alternate land uses in salty and water scarcity areas. Int $J$ Ecol Environ Sci,35(1), pp.5366.

Dwivedi, R.S., Sreenivas, K. and Ramana, K.V., 1999. Inventory of salt-affected soils and waterlogged areas: a remote sensing approach. International Journal of Remote Sensing, 20(8), pp.1589-1599.

HUANG, L.H., 2009. 2, LIANG Zheng-wei1, 2, MA Hongyuan1, 2 (1.Northeast Institute of Geography and Agricultural Ecology, Chinese Academy of Sciences, Changchun 130012, China; 2.Da'anSodic Land Experiment Station, Da'an 131317, China); Effects of saline-sodic stress on the photosynthesis rate, transpiration rate and water use efficiency of Leymuschinensis [J]. ActaPrataculturaeSinica, 5.

Jayawardane, N.S., Biswas, T.K., Blackwell, J. and Cook, F.J., 2001.Management of salinity and sodicity in a land FILTER system, for treating saline wastewater on a saline-sodic soil. Soil Research, 39(6), pp.1247-1258.

Kallar grass: a plant for saline land. Nuclear Institute for Agriculture and Biology, 1986.

Mandal, A.K. and Sharma, R.C., 2011. Delineation and characterization of waterlogged salt affected soils in IGNP using remote sensing and GIS. Journal of the Indian Society of Remote Sensing, 39(1), pp.39-50.

McFarlane, D.J. and Williamson, D.R., 2002. An overview of water logging and salinity in southwestern Australia as related to the 'Ucarro'experimental catchment. Agricultural Water Management, 53(1-3), pp.5-29.

Mendoza, R., Escudero, V. and García, I., 2005.Plant growth, nutrient acquisition and mycorrhizal symbioses of a 
waterlogging tolerant legume (Lotus glaber Mill.) in a salinesodic soil. Plant and soil, 275(1-2), pp.305-315.

Pal, D.K., Srivastava, P., Durge, S.L. and Bhattacharyya, T., 2003. Role of microtopography in the formation of sodic soils in the semi-arid part of the Indo-Gangetic Plains, India. Catena, 51(1), pp.3-31.

Panda, S.N., Khepar, S.D. and Kaushal, M.P., 1996.Interseasonal irrigation system planning for waterlogged sodic soils. Journal of irrigation and drainage engineering, 122(3), pp.135-144.

Pandey, V.C., Singh, K., Singh, B. and Singh, R.P., 2011. New approaches to enhance eco-restoration efficiency of degraded sodic lands: critical research needs and future prospects. Ecological Restoration, 29(4), pp.322-325.

Sharma, B.R. and Minhas, P.S., 2005.Strategies for managing saline/alkali waters for sustainable agricultural production in
South Asia. Agricultural Water Management, 78(1-2), pp.136151.

Singh, K., Singh, B. and Singh, R.R., 2012. Changes in physico-chemical, microbial and enzymatic activities during restoration of degraded sodic land: Ecological suitability of mixed forest over monoculture plantation. Catena, 96, pp.5767.

Singh, K., Singh, B. and Singh, R.R., 2013. Effect of land rehabilitation on physicochemical and microbial properties of a sodic soil. Catena, 109, pp.49-57.

Sujatha, G., Dwivedi, R.S., Sreenivas, K. and Venkataratnam, L., 2000. Mapping and monitoring of degraded lands in part of Jaunpur district of Uttar Pradesh using temporal spaceborne multispectral data. International Journal of Remote Sensing, 21(3), pp.519-531. 